\title{
Extramammary Paget's Disease in the Pubic Region: a Case Report
}

\author{
Slobodan STOJANOVIĆ ${ }^{1,4^{*}}$, Nada VUČKOVIĆ ${ }^{2,4}$, Pavle JEREMIĆ ${ }^{3,4}$, Biljana JEREMIĆ ${ }^{1}$ \\ ${ }^{1}$ Clinic of Dermatovenereology Diseases, Clinical Center of Vojvodina, Novi Sad, Serbia \\ ${ }^{2}$ Center for Pathology and Histology, Clinical Center of Vojvodina, Novi Sad, Serbia \\ ${ }^{3}$ Clinic of plastic and reconstuctive surgery, Clinical Center of Vojvodina, Novi Sad, Serbia \\ ${ }^{4}$ Faculty of Medicine, University of Novi Sad, Serbia
}

*Correspondence: Slobodan STOJANOVIĆ, E-mail: slobodanstojanovicns@sbb.rs

UDC $616.5: 618.16]-006.6-091.8$

\section{DE GRUYTER OPEN}

\begin{abstract}
The authors present a case of a patient with extramammary Paget's disease in the pubic region treated by a dermatologist with a private practice for almost 4 years before incisional biopsy was performed. A thorough examination showed no evidence of malignancies of internal organs, whereas definite diagnosis was made by excision of the entire skin lesion and histopathological analysis.

With regard to multiple criteria, findings in our patient were consistent with current literature data, but interestingly, the primary extramammary Paget's disease has not spread into deeper tissues.
\end{abstract}

\section{Key words}

Disease, Extramammary; Skin Neoplasms; Genitalia, Female; Reconstructive Surgical Procedures; Histological Techniques

Cxtramammary Paget's disease (EMPD) is a Crare cutaneous malignancy characterized by intraepithelial adenocarcinoma outside the mammary gland. Mammary Paget's disease (MPD) is almost always associated with a ductal carcinoma $(1,2)$. EMPD mostly occurs in older people with a predilection for the apocrine-rich anogenital skin and less commonly for the axilla (1). The disease usually manifests as a sharply defined erythema with polygonal borders (1, $2)$, but centrifugal tumor growth is also possible (1, 2 ). The disease is rare, with an unclear pathogenesis, so there is no standard treatment algorithm; it commonly requires wide excision over the clinically visible borders $(2,3,4)$. Long-term monitoring is recommended due to common recurrence (1). The diagnosis of EMPD is usually made histopathologically and it has a few stages $(1,5)$.

\section{Case Report}

An 80-year-old female patient presented with skin lesions in the pubic region, over labia majora, with slightly elevated erythema, small erosions and slight oozing. At the beginning, the condition was not associated with pain or itching. The patient visited a private dermatologist. The submitted documentation showed that the patient had a sharply demarcated erythematous plaque of $30 \times 30 \mathrm{~mm}$ in diameter; local therapy included betamethasone dipropionate $0.05 \%$ in combination with clotrimazole tablets $1 \%$, and $0.1 \%$ gentamicin sulfate cream. Since then, the patient visited the same dermatologist seven times; she was treated under the clinical diagnosis of candidomycetic dermatitis of the pubic region, but without satisfactory results.

After more than half a year of unsuccessful treatment and development of severe itching, the patient visited another dermatologist, but after 3 months, there was no improvement. Over the next year, she experienced moderate itching and burning once a month. She used mometasone furoate $0.1 \%$ cream in the evening, for 5-6 days at least once a month. As the disease was progressing, the patient 
presented with a burning sensation even when using water.

In October 2010, the patient visited the Dermatovenereology Department of the Clinical Center of Vojvodina in Novi Sad for the first time. Physical examination revealed a skin lesion in the pubic region at about $1 \mathrm{~cm}$ above the anterior commissure of the labia majora of $60 \times 50 \mathrm{~mm}$ in diameter. It was a sharply demarcated, erythematous dry plaque, without oozing, associated only with slight burning sensation.

The patient visited her private dermatologist again and underwent incisional biopsy (performed for diagnostic purposes, in order to plan reconstructive surgery - which is usually done in all major procedures). The sample (Figure 1) was sent for histopathological examination, under suspicion of Bowen's disease, and the result was superficial melanoma (Clark 2, Breslow $0.5 \mathrm{~mm}$ ).

The patient was referred to the Clinic of Plastic and Reconstructive Surgery, Clinical Center of Vojvodina, NoviSad, considering the fact that the above histopathological analysis indicated complete excision of the lesion. The internist examination showed that there were no contraindications for surgery. All relevant preoperative laboratory and other findings, including gynecological and gastroenterological ultrasound and $\mathrm{X}$-rays, were within the reference values.
Under general anesthesia, the patient underwent total excision of the lesion, with vacuum drainage, local skin transposition flap, and a protective lining of $2.5 \mathrm{~cm}$. The removed tissue included the skin with subcutaneous fat tissue, $8,3 \times 6,6 \mathrm{~cm}$ in diameter, with the brown lesion and the clinically unaffected surrounding area, which was sent for histopathological analysis. The obtained findings showed that the lesion comprised grouped cubic and polygonal cells within the epidermis, individual cells at all levels of the epidermis, and adenoid formations on the dermoepidermal border; tumor cells were HMB45 negative and CK7 positive; the base of the tumor consisted of connective tissue pointing to the previous incisional intervention; the tumor tissue was entirely removed. Based on this description, the diagnosis of extramammary Paget's disease (EMPD) was made (Figures 2 and 3). Analysis of histopathological findings was done at the Institute of Pathology and Histology, Clinical Center of Vojvodina, Novi Sad, Serbia, including revision of the first biopsy, performed at the private clinic, and both confirmed the diagnosis of EMPD.

There were no complications during the postoperative period, and the postoperative wound healing was uneventful. At check-ups, all results were within normal values without regional lymph node

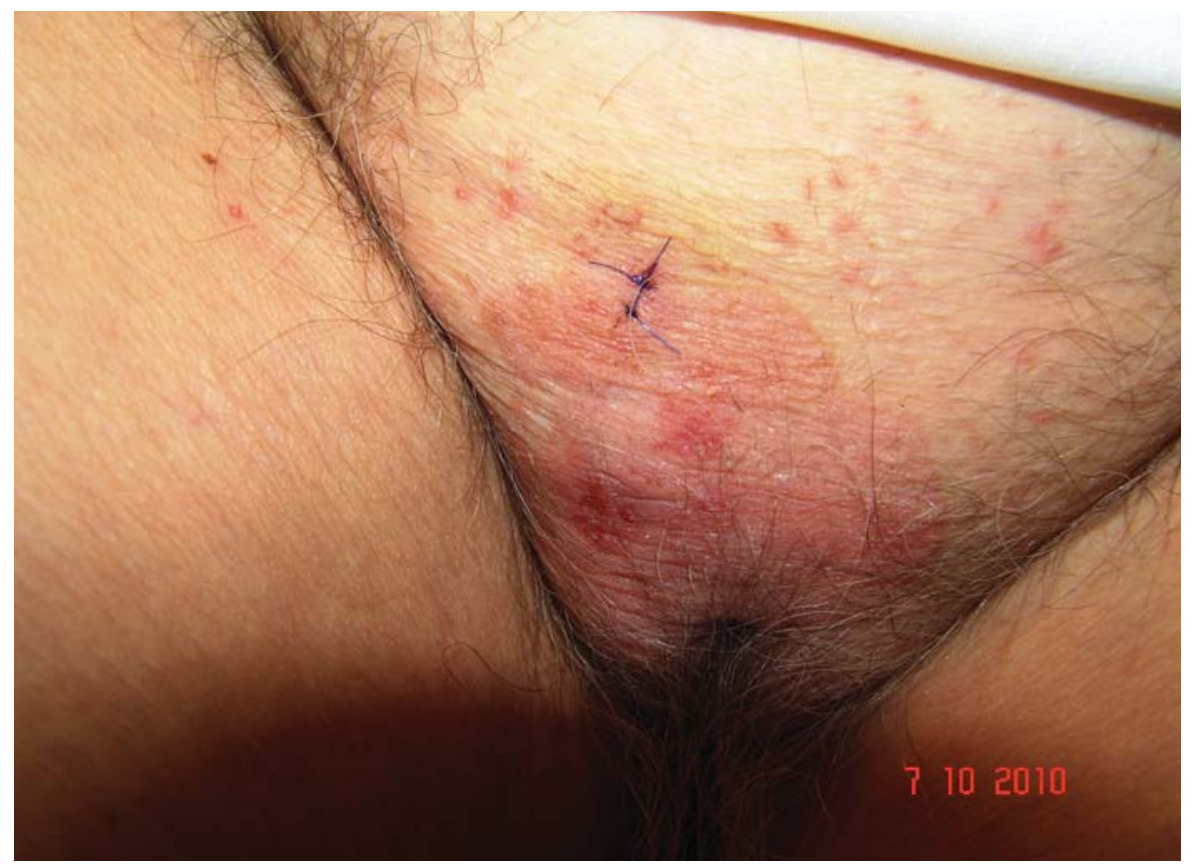

Figure 1. Paget's disease of the pubic region with a visible locus of the first incisional biopsy 


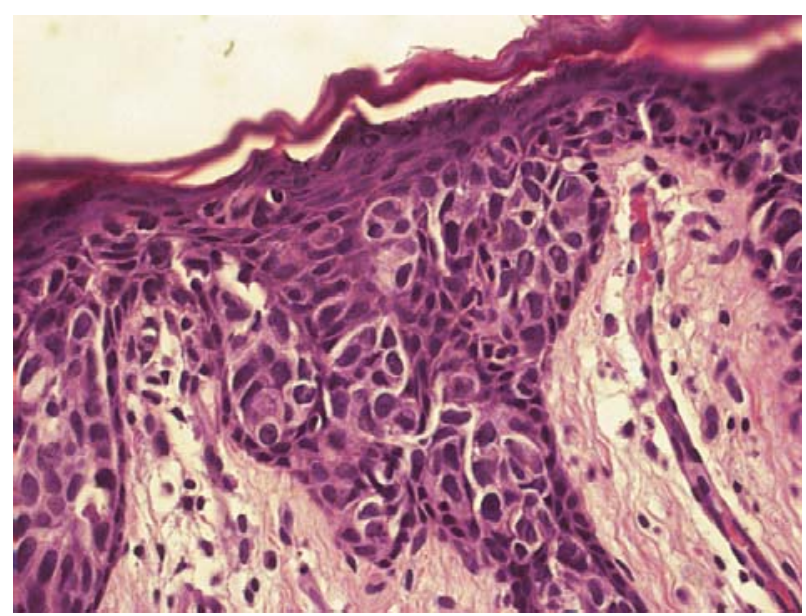

Figure 2. Electron micrograph of multiple Paget cells in the epidermis (HEx400)

involvement or other complications. Gynecological and gastroenterological examination and ultrasound findings, as well as extensive double contrast irigography, showed that EMPD was not associated with any other genital or anorectal disease.

The patient's medical history showed that she had three gynecological surgical interventions for benign tumors of the vulva, endometritis, and uterine cervical polyps at the age of 41, 44 and 48, respectively; at the age of 71 , the patient underwent surgery for urethral polyps; bougienage of urethral stenosis was performed at the age of 77; two surgeries were also performed for removal of facial basal cell carcinoma at the age of 79 and 84 , respectively.

\section{Discussion}

In 1874, Sir James Paget reported a case series of 15 patients with chronic, eczematoid ulcerations of the nipple in association with breast cancer (6). Sir Paget suggested that these lesions were initial or associated with breast cancer (6). In contrast, in 1889, Henry Radcliffe Crocker was first to describe a case of EMPD of the scrotum and glans penis (7). The first detailed histopathological description of Paget's disease was given by Ferdinand-Jean Darier in 1889 (8).

In the early 20 th century, there was a conceptual hypothesis about two forms of Paget's disease (PD): first - as a precancerous condition without a direct connection to the tumor, and second - intraepithelial metastasis of already existing breast cancer. Although this conceptual hypothesis has not been proven as

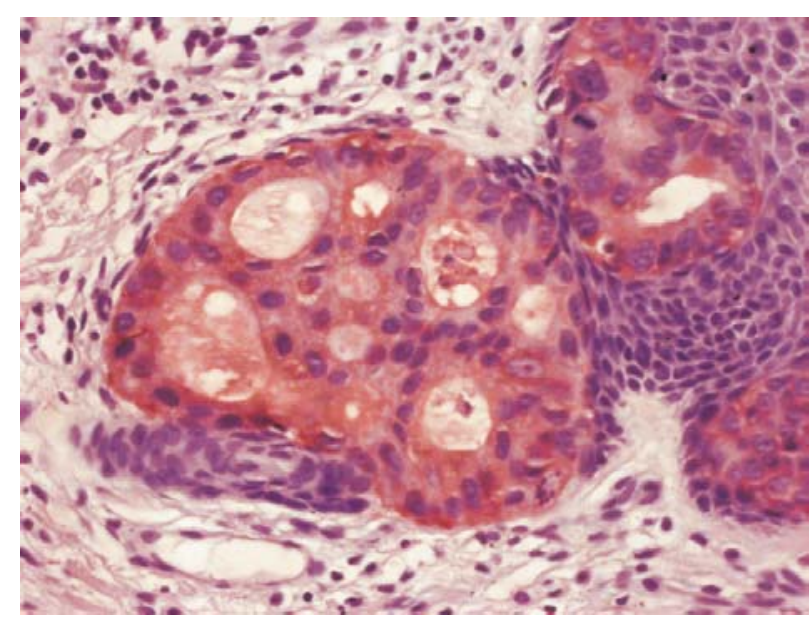

Figure 3. Electron micrograph of Paget cells forming an adenoid pattern (CK7x 400)

true for $\mathrm{PD}$, it provides a basis for understanding the pathology of primary EMPD form resulting in skin adnexal glandular structures (apocrine gland carcinoma), as well as its potential secondary manifestations, that is intraepithelial epidermotropic metastatic malignancies from the adjacent or internal organs (2).

The incidence of EMPD is very low, and it can be indirectly evaluated based on the number of new cases of breast cancer in women, because PD accounts for $0.7-4.3 \%$ (9), whereas EMPD accounts for $6.5 \%$ of all forms of PD (2). EMPD is more common in women than in men, the sex ratio ranges from $3-4.5$ $: 1$, and it most often affects the elderly $(10,11)$. The average age at the time of diagnosis is $64-72$ years, and $90 \%$ of patients are over 50 years of age (11). As for the age distribution, one should keep in mind that the disease is often present for years or even decades before it is manifested (11).

Clinical EMPD affects parts of the skin with apocrine glands. Predilection sites include the anogenital region, rarely axillae, and least rarely both anogenital region and axillae (12). The most commonly affected site is the vulva (11) and labia majora. Taking into account the centrifugal tumor growth, the entire anogenital region may be infiltrated, so in advanced stages of the disease it is often impossible to identify the origin of the primary neoplasm. This may be significant, because EMPD may also occur as an expression of the primary tumor, which affected some internal organs of the body. The risk of associated 
malignancy and EMPD in the perianal area is 25 $35 \%$, which is significantly higher than in relation to a possible malignancy in the genital area, which is approximately $4-7 \%(13,14)$, being the case in in our patient. Other possible sites of EMPD include eyelids, outer ear canal, the umbilical region, trunk and limbs $(15,16)$.

Depending on the site and duration of the disease, the clinical appearance of EMPD varies significantly. Large, extended lesions may be irregular with poorly defined borders, but the centrifugal growth pattern leads to the formation of polygonal borderline, providing a diagnostic clue as in our case. Some of the rare morphological characteristics of EMPD include neoplastic alopecia, sclerodermiform macular and lichenoid papules (17). Metastasis of primary EMPD is characterized by per continuitatem, lymphatic, or more rarely hematogenous spread. Out of the 76 patients with primary EMPD, Hatta and associates reported metastases in $17 \%$ of cases (18). Secondary EMPD, excluded in our patient, is an intraepithelial metastasis of internal organ tumors: colonic cancer, uterine cervix cancer, urinary bladder, urethral and prostatic cancer (11).

Like in our patient, the diagnosis of EMPD is usually made after a few years, due to a variety of clinical presentations and the rarity of the disease. On average, the disease is diagnosed two years after the appearance of initial symptoms (11). There are some reports about EMPD existing up to 30 years before they were diagnosed (12). The diagnosis of EMPD is confirmed by the presence of Paget's cells (PCs). They are usually about two times larger than the surrounding keratinocytes, round-shaped, with clear cytoplasm and large pleomorphic nuclei. With a few exceptions, PCs contain a high percentage of mucin, which can be proved by periodic acid-Schiff (PAS) and Alcian blue staining, depending on the content of mucopolysaccharides, used for differential diagnosis (18). PCs are usually isolated cells or form irregular groups: the so-called epidermal-Paget pattern. If other malignancies develop within the epidermis, such as malignant melanoma, adenocarcinoma or mycosis fungoides, it is known as Paget's phenomenon (19). If PCs are only intraepidermal, like in our patient, or found in the adnexal epithelium, the tumor is considered to be carcinoma in situ. However, penetration of the basal membrane is associated with adnexal carcinoma (20).

Histogenesis of EMPD is not fully understood. Electron microscopy studies indicate to gland origin of PCs (e.g., a large Golgi apparatus and numerous mitochondria, as well as the presence of microvilli and secretory vacuoles) (20). Immunohistochemical studies are of utmost importance for histogenesis, but also for the diagnosis and classification of PCs, and in differential diagnosis. Cytokeratin 7 (CK-7) is a very useful antibody for confirming the diagnosis of MPD as well as EMPD. As in our patient, tumor cells in the EMPD stained consistently for this antibody, while the surrounding epidermis was negative (18). Apart from low molecular weight cytokeratin, such as CK 7, other antigens present in apocrine and eccrine sweat glands, can be routinely identified in PCs, e.g. CEA (carcinoembryonic antigen) $(21,22)$. Detection of these antigens confirms the glandular origin of PCs. Although there is a growing body of evidence in favor of histogenetic origin of PCs from apocrine sweat glands, pluripotent stem cells have also been considered as possible origin (10).

Based on clinical, histopathological and immunohistochemical analyses, it is now a common belief that there are two different forms of EMPD in regard to pathogenesis and prognosis. Primary EMPD develops in the epidermis and it is considered to be carcinoma in situ. Secondary EMPD is less frequent, with intraepithelial spreading of the primary tumor (17). Just as Paget's breast cancer, EMPD may also originate from a primary cancer of the apocrine sweat glands, or the neighboring anorectal or urogenital organs. Nevertheless, some authors suggest that the lack of evidence, particularly in cutaneous adnexal cancers (possibly as a result of inadequate histological analysis) may indicate focal changes in the apocrine sweat glands. Histologically, it is impossible to distinguish the course of disease progression, especially in advanced stages (2). Associated neoplasms include cutaneous adnexal carcinomas, as well as rectal, colonic, bladder, prostatic, urethral, and cervical malignancies.

A typical differential diagnosis of EMPD includes: contact or seborrheic dermatitis, inverse psoriasis, perianal streptogenic dermatitis, mycotic infections (positive mycological finding does not exclude EMPD 
in case of a secondary fungal infection), lichen simplex (severe lichenification), lichen planus, lichen sclerosus et atrophicus, circumscribed morphea, benign pemphigus (Hailey-Hailey disease), histiocytosis, necrolytic migratory erythema and genital warts (17, 23, 24). In regard to skin neoplasms, differential diagnosis of EMPD includes: Bowen's disease (of the $\mathrm{anal} / \mathrm{perianal} / \mathrm{vulvar}$ area), and vulvar intraepithelial neoplasia (17, 24). Melanoma, squamous cell carcinoma, intraepidermal sebaceous carcinoma, secondary Paget's disease and adenocarcinoma should be ruled out histopathologically (25).

Surgical excision remains the treatment of choice in primary EMP. Considering the age of patients, complicated surgical procedures are often not recommended due to the location or size of the tumor. Required surgical interventions in the anogenital area are often associated with a decreased quality of life. Apart from this, there is a high rate of postoperative recurrence. Literature data indicate to $8 \%$ recurrence after surgical excision of EMPD, performed with $2 \mathrm{~cm}$ margins (10). Other studies, of conventional excision procedures and safety margins of $1-2 \mathrm{~cm}$, reported recurrence of $15-50 \%$ in the vulvar region (11). The average recurrence rate for all sites is $35-44 \%$ (26). Lower recurrence rates have been reported after Mohs microscopic surgery $(8$ - 26\%) (27). Other forms of therapy of EMPD include: radiotherapy, carbohydrate laser therapy, photodynamic therapy, topical use of 5-fluorouracil, and so on. Treatment options for secondary EMPD are basically the same as for the primary form of the disease $(2,28)$. It is of utmost importance to treat the associated visceral malignancy.

The prognosis for the primary EMPD is generally favorable, although it may depend on the duration of the disease. The mortality rate is $13-18 \%$ (12), and 5 -year survival is $72 \%$ (29). However, the prognosis is much worse if invasive growth is present at the time of diagnosis. The prognosis of secondary EMPD, associated with cancer of adjacent organs, depends on the prognosis of the primary visceral tumor. The median survival among patients with secondary EMPD is only 3 years (30).

\section{Conclusion}

This is a case report of a patient with extramammary Paget's disease without visceral malignancy and successful surgical management.

\section{Abbreviations}

EMPD - extramammary Paget's disease

MPD - mammary Paget's disease

HMB 45 - human melanoma, black-45

CK7 - cytokeratin7

PD - Paget's disease

PCs - Paget cells

PAS - periodic acid-Schiff

CEA - carcinoembryonic antigen

\section{References}

1. Wagner G, Sachse MM. Extramammary Paget disease: clinical appearance, pathogenesis, management. J Dtsch Dermatol Ges 2011;9:448-54.

2. Kyriazanos ID, Stamos NP, Miliadis L, Noussis G, Stoidis CN. Extra-mammary Paget's disease of the perianal region: a review of the literature emphasizing the operative management technique. Surg Oncol 2011;20:e61-71.

3. Ekwueme KC, Zakhour DH, Parr NJ. Extramammary Paget's disease of the penis: a case report and review of the literature. J Med Case Rep 2009;3:4.

4. Juang GD, Lin MY, Hwang T ShI. Extramammary Paget's disease of the scrotum. J Chin Med Assoc 2011;74:325-8.

5. Venkatesh RR, David HH. Extramammary Paget's disease. Com Oncol 2004;1(2):109-15.

6. Paget J. One disease of the mammary areola proceeding cancer of the mammary gland. St Barth Hosp Rep 1874;10:87-9.

7. Crocker HR. Paget's disease, affecting the scrotum and penis. Trans Pathol Soc Lond 1889; 40:187-91.

8. Darier FJ. Sur un nouvelle forme de psorrospermose cutanee: la maladie de Paget du reammelon. C R Soc Biol. 1889;41:2948.

9. Kanitakis J. Mammary and extramammary Paget's disease. J Eur Acad Dermatol Venereol 2007;21:581-90.

10. Jones RE Jr, Austin C, Ackerman AB. Extramammary Paget's disease. A critical reexamination. Am J Dermatopathol 1979;1:101-32.

11. Shaco-Levy R, Bean SM, Vollmer RT, Jewell E, Jones EL, Valdes CL, et al. Paget disease of the vulva: a study of 56 cases. Eur J Obstet Gynecol Reprod Biol 2010;149:86-91.

12. Hatta N, Yamada M, Hirano T, Fujimoto A, Morita R. Extramammary Paget's disease: treatment, prognostic factors and outcome in 76 patients. Br J Dermatol 2008;158:313-8.

13. Zollo JD, Zeitouni NC. The Roswell Park Cancer Institute experience with extramammary Paget's disease. Br J Dermatol 2000;142:59-65.

14. Neuhaus IM, Grekin RC. Mammary and extramammary Paget disease. In: Wolff K, Goldsmith LA, Katz SI, Gilchrest BA, Paller AS, Leffell DJ, editors. Fitzpatrick's dermatology in general medicine. 7th ed. New York: McGraw-Hill; 2008. p. 1094-8.

15. Worthon CM, Patterson JB. Carcinoma of Moll's glands with extramammary Paget's disease of the eyelid. Cancer 
1955;8:1009-15.

16. Gonzales-Castro J, Iranzo P, Palou J, Mascaró JM. Extramammary Paget's disease involving the external ear. $\mathrm{Br} \mathrm{J}$ Dermatol 1998;138:914-5.

17. Lloyd J, Flanagan AM. Mammary and extramammary Paget's disease. J Clin Pathol 2000;53: 742-9.

18. Hatta N, Yamada M, Hirano T, Fujimoto A, Morita R. Extramammary Paget's disease: treatment, prognostic factors and outcome in 76 patients. Br J Dermatol 2008;158:313-8.

19. Calonje E. Tumours of the skin appendages. In: Burns T, Breathnach S, Cox N, Griffith SC, editors. Rook's textbook of dermatology. 8 th ed. Oxford: Blackwel Publishing; 2010. p. 53.1-44.

20. Lupton G, Graham JH. Mammary and extramammary Paget's disease. In: Friedman RJ, Rigel DS, Kopf AW, Harris MN, Baker D, editors. Cancer of the skin. Philadelphia: WB Saunders; 1991. p. 217-36.

21. Ordonez NG, Awalt H, Mackay B. Mammary and extramammary Paget's disease: An immunocytochemical and ultrastructural study. Cancer 1987;59:1173-83.

22. Lautier R, Achtelik WV, Wolff HH. Immunhistochemische Untersuchung bei mammären und extramammären Morbus Paget weisen auf eine apokrine Differenzierung hin. Z Hautkr 1990;65:571-4.

23. Kanitakis J. Mammary and extramammary Paget's disease. J
Eur Acad Dermatol Venereol 2007;21:581-90.

24. Honda Y, Egawa K. Extramammary Paget's disease not only mimicking but also accompanying condyloma acuminatum. A case report. Dermatology 2005;210:315-8.

25. Hilliard NJ, Huang C, Andrea A. Pigmented extramammary Paget's disease of the axilla mimicking melanoma: case report and review of the literature. J Cutan Pathol 2009;36:995-1000.

26. Zollo JD, Zeitouni NC. The Roswell Park Cancer Institute experience with extramammary Paget's disease. Br J Dermatol 2000;142:59-65.

27. Hendi A, Brodland DG, Zitelli JA. Extramammary Paget's disease: surgical treatment with Mohs micrographic surgery. J Am Acad Dermatol 2004;51:767-73.

28. Kitagawa KH, Bogner P, Zeitouni NC. Photodynamic therapy with methyl-aminolevulinate for the treatment of double extramammary Paget's disease. Dermatol Surg 2011;37:10436.

29. Siesling S, Elferink MAG, van Dijck JA, Pierie JP, Blokx WA. Epidemiology and treatment of extramammary Paget disease in the Netherlands. Eur J Surg Oncol 2007;33:951-5.

30. Zhu Y, Ye DW, Yao XD, Zhang SL, Dai B, Zhang HL, et al. Clinicopathological characteristics management and outcome of metastatic penoscrotal extramammary Paget's disease. Br J Dermatol 2009;161:577-82.

\section{Ekstramamarna Padžetova bolest u pubičnoj regiji - prikaz slučaja}

\section{Sažetak}

Autori prikazuju slučaj bolesnice sa ekstramamarnom Padžetovom bolesti u pubičnoj regiji koja je lečena kod dermatologa u privatnoj praksi skoro dve godine pre incizione biopsije promene. Detaljnom pretragom nije utvrđeno istovremeno prisustvo maligniteta unutrašnjih organa, a definitivna dijagnoza je postavljena ekscizijom kožne promene u celosti i odgovarajućom patohistološkom analizom.

Po mnogim kriterijumima naša bolesnica odgovara navodima u savremenoj literaturi, ali je u ovom slučaju bilo zanimljivo to da nije došlo do širenja neoplazme sa mesta primarnog ekstramamarnog M. Padžet u dubinu tkiva.

\section{Ključne reči}

Ekstramamarna Padžetova bolest; Kožne neoplazme; Ženske genitalije; Rekonstruktivne hirurške procedure; Histološke tehnike 